\title{
External Auditory Canal Ceruminous Adenoma
}

National Cancer Institute

\section{Source}

National Cancer Institute. External Auditory Canal Ceruminous Adenoma. NCI Thesaurus. Code C6088.

A benign epithelial neoplasm derived from ceruminous glands in the external auditory canal. It presents as a grey mass covered by skin. It is characterized by a proliferation of glands composed of cells with abundant eosinophilic and granular cytoplasm. 